\title{
ACANTHOLYTIC SQUAMOUS CELL CARCINOMA OF PREPUCE
}

Mamina Bhoi ${ }^{1}$, Sarvesh B. M², P. Viswanathan ${ }^{3}$, Rehana Tippoo ${ }^{4}$

\section{HOW TO CITE THIS ARTICLE:}

Mamina Bhoi, Sarvesh B. M, P. Viswanathan, Rehana Tippoo. "Acantholytic Squamous Cell Carcinoma of Prepuce". Journal of Evolution of Medical and Dental Sciences 2014; Vol. 3, Issue 13, March 31;

Page: 3360-3366, DOI: 10.14260/jemds/2014/2292

ABSTRACT: An uncircumcised 65 year male, with history of phimosis presented with retention of urine and ulceration and bleeding in the prepuce. Circumcision was done under local anesthesia which revealed an ulcero-proliferative growth involving the prepuce and glans. The prepucial skin was sent for histopathological examination. The diagnosis was histopathologically confirmed as Acantholytic Squamous Cell Carcinoma. Acantholytic squamous cell carcinoma is a highly malignant, unusual variant of squamous cell carcinoma invading deeper anatomic structures and is associated with a higher incidence of regional metastasis and mortality.

KEYWORDS: Squamous cell carcinoma, acantholytic, pseudoglandular, lichen planus.

INTRODUCTION: Lichen planus predisposes to squamous cell carcinoma and $1 \%$ becomes squamous cell carcinoma with invasion. ${ }^{1}$ Vesicular lichen planus is rare. It shows vesicles situated only on some of the pre-existing lesions. ${ }^{2}$ It is different from so called, lichen planus pemphigoides, in which the eruption is more disseminated and the bullae are more extensive, ${ }^{3}$ arising from papules of lichen planus and from normal appearing skin. ${ }^{2,4}$

Although lichen planus pemphigoides and bullous pemphigoid manifests in different ways clinically, the same antigen may be involved in immunopathogenesis of these two diseases (Bullous pemphigoid antigen 180). Ulcerative lichen planus, an uncommon variant of lichen planus shows bullae erosions and painful ulcerations. Acantholytic squamous cell carcinoma is an unusual variant of squamous cell carcinoma characterised by prominent acantholysis and formation of pseudo glandular spaces showing tubular and alveolar formation. ${ }^{5}$ It is a result of dyskeratosis and subsequent acantholysis. So it is also called pseudo glandular or adenoid squamous cell carcinoma. The median age of the patients is 54 years. ${ }^{6}$

Found almost commonly in sun exposed skin of elderly patients, especially on the face and ears. They are also seen on the vermilion border of lower lip. Two instances of occurrence on the oral mucosa have been reported, both are recurrences after radiotherapy. Cases of Squamous cell carcinoma have been reported in association with lichen sclerosus et atrophicus and lichen planus. ${ }^{7}$

We present a very rare case of acantholytic squamous cell carcinoma with lichen planus of prepucial skin.

CASE HISTORY: An uncircumcised 65 year old male patient, who complained of phimosis, difficulty in micturition for 3 months with history of ulceration and bleeding. Phimosis was noted. Evidence of ulceration and bleeding on manipulation was noted. No growth was evident externally.

Prepuce could not be retracted. Circumcision was done under local anesthesia. Surgery revealed an ulceroproliferative, grey white growth of prepuce and glans. The excised tissue was sent for histopathological examination. 
MACROSCOPY: Container had prepucial skin exhibiting an ulcer-proliferative growth .The prepucial skin was measuring $3 \times 2 \times 1$ centimeter [Figure 1]. The ulceroproliferative growth was measuring $2.5 \times 1.5$ centimeter. The tissue was friable, grey white [Figure 2] and all tissue was processed for study.

LIGHT MICROSCOPIC FINDINGS - H \& E SECTIONS: Section studied shows areas of lichen planus [Figure $3 \mathrm{a}$-b] [Figure 4a] with intraepithelial edema [Figure $4 \mathrm{a}-\mathrm{b}$ ] and suprabasilar bullae formation [Figure 3c] [Figure 4b]. Dense infiltration of mononuclear cells abetting the squamo-epithelial junction is noted [Figure 3a]. Some areas show malignant squamous cells in sheets and nests diffusely infiltrating the deeper tissue and they tend to form keratin pearls [Figure 3b] [Figure 7a]. Perineurial invasion was noted [Figure 7b]. There is also mucoid degeneration of ground substance [Figure 8 a] and pseudoglandular differentiation of tumour cells [Figure 5b] [Figure $6 \mathrm{a}-\mathrm{b}$ ] and [Figure 8b]. The pseudoglandular spaces tend to form cribriform pattern which contain acantholytic tumor cells [Figure 6a, b, c, d].

- Features were consistent with the diagnosis of Acantholytic Squamous Cell Carcinoma with areas of lichen planus.

DISCUSSION: Acantholytic squamous cell carcinoma tumors tend to be large. Tumour size of greater than $1.5 \mathrm{~cm}$ correlates with the risk of an adverse outcome. These tumors represent squamous cell carcinoma of lobular growth in which there is considerable dyskeratosis with individual cell keratinization resulting in acantholysis in the centre of the lobular formation. The pseudoglandular spaces contain acantholytic neoplastic keratinocytes sometimes admixed with keratin material and necrotic debris. The adenoid changes may be seen in only a portion of a squamous cell carcinoma or throughout the lesion.

Not infrequently, an actinic keratosis of the acantholytic type is seen overlying the lesion.In Bullous lesions acantholytic cells are present within the bullae, and these are observed as dispersed, numerous, peculiar intermediate squamous cells with large nuclei and nucleoli called as acantholytic cells of Tzanck. ${ }^{8}$ The origin of these cells are due to epithelial oedema and loss of intercellular attachment due to circulating IgG autoantibodies against bullous pemphigoid antigen 180 which is a transmembrane hemidesmosomal glycoprotein of the basal keratinocytes that spans the lamina lucida. 9,10

There are tubular and alveolar lumina lined with one or several layers of epithelium. In areas in which the lumina are lined by a single layer of epithelium, the epithelial cells resemble glandular cells, but in areas with several layers of epithelium, squamous and partially keratinized cells usually form the inner layers. These ductal changes probably are induced by the surrounding inflammatory infiltrate. Pseudoglandular squamous cell carcinoma show higher grade of malignancy, invade deeper anatomic structures, and are associated with a higher incidence of regional metastasis and mortality.

The differential diagnosis includes:

1) Gland forming penile tumours (surface adenosquamous, mucoepidermoid and urethral carcinomas):- No true glandular differentiation with mucin is observed in Acantholytic Squamous cell Carcinoma.

2) The angiosarcomatoid variant of sarcomatoid carcinoma: - No spindle shaped cells are seen in Acantholytic Squamous cell Carcinoma. 


\section{REFERENCES:}

1. Sigurgeirsson B, Lindel of B. Lichen planus and malignancy: an epidemiologic study of 2071 patients and a review of the literature. Arch Dermatol 1991; 127:1684.

2. Saurat JH, Guinepain MT, Didierjean L, et al. Coexistence d'un lichen plan et d'un pemphigoide bulleuse. Ann Dermatol Venereol 1977; 104:368.

3. Gawkrodger DJ, Stavropoulos PG, McLaren KM, et al. Bullous lichen planus and lichen planus pemphigoides: clinicopathological comparisons. Clin Exp Dermatol 1989; 14:150.

4. Hintner H, Tappeiner G, Honigsmann H, et al. Lichen planus and bullous pemphigoid. Acta Derm Venereol Suppl (Stockh) 1979; 85:71.

5. Bain L, Geronemus R. The association of lichen planus of the penis with squamous cell carcinoma in situ and with verrucous squamous carcinoma. J Dermatol Surg Oncol 1989, 15: 413-417.

6. Pride HB Miller OF, Tyler WB. Penile squamous cell carcinoma arising from balanitis xerotica obliterans. J Am Acad Dermatol 1993, 29: 469-473.

7. Lasser A, Cornog JL, Morris J MCL. Adenoid squamous cell carcinoma of the vulva. Cancer 1974; 33:224.

8. Tzanck A, Melki GR, Aron-Brunetiere R. Cytodiagnosis of pemphigus. Acta Unio Int Contra Cancrum 7:727-729, 1951.

9. Zillikens D. BP 180 as the common autoantigen in blistering diseases with different clinical phenotypes. Keio J Med 2002; 51:21.

10. Hsu S, Ghohestani RF, Uitto J. Lichen planus pemphigoides with IgG autoantibodies to the 180 kd bullous pemphigoid antigen (type XVII collagen). J Am Acad Dermatol 2000; 42:136.

\section{MACROSCOPIC PICTURE:}

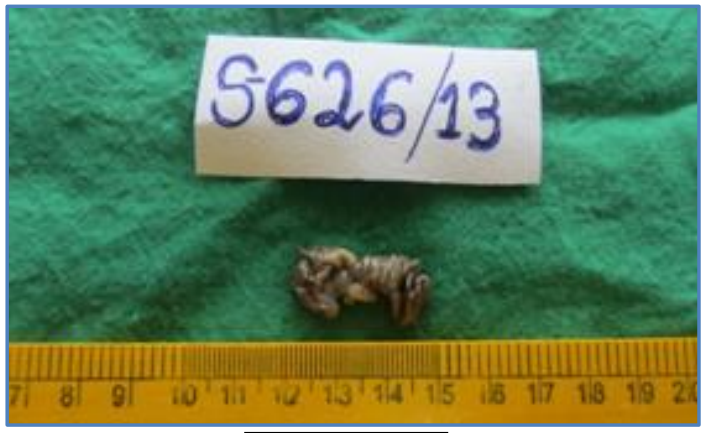

Figure 1

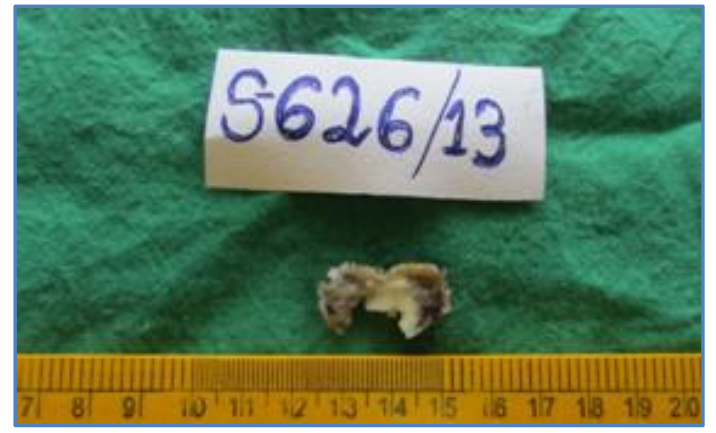

Figure 2

Fig. 1: Prepucial skin with grey white lesion

Fig. 2: Cut section shows grey white, friable lesion. 


\section{CASE REPORT}

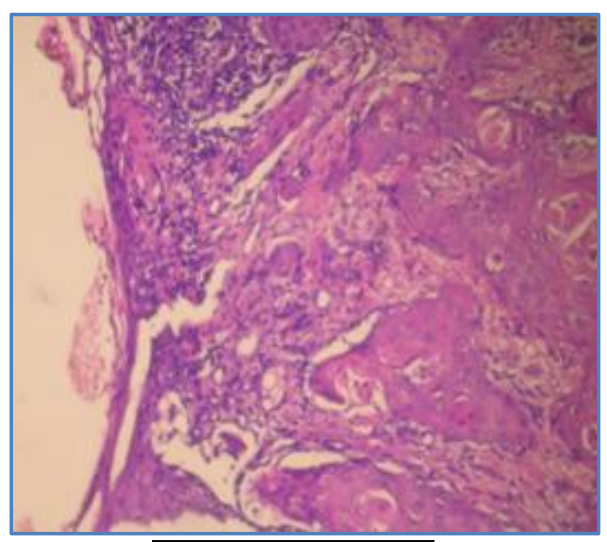

Figure 3 (a)

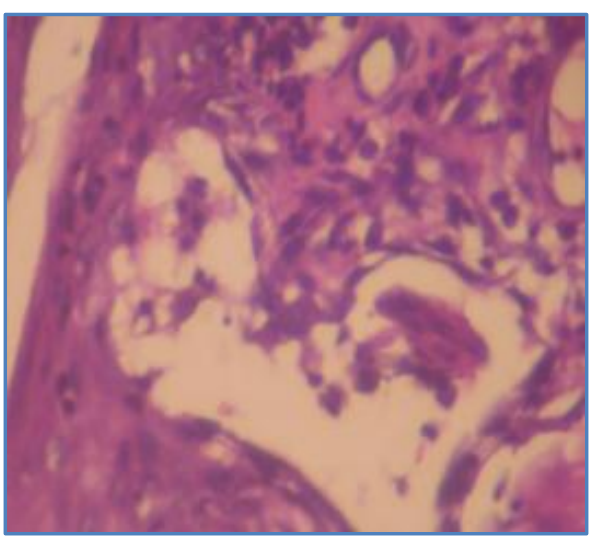

Figure 3 (b)

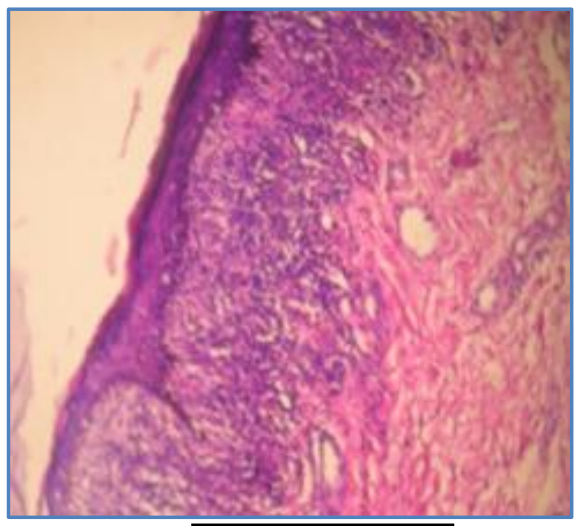

Figure 3 (c)

Fig. 3(a): Evidence of lichen planus with dense mononuclear infiltration (10X).

Fig. 3(b): Areas of lichen planus with squamous cell carcinoma. Tumor cells tend to form keratin pearls (10X).

Fig. 3(c): Suprabasal bulla containing acantholytic squamous tumor cells (40X)

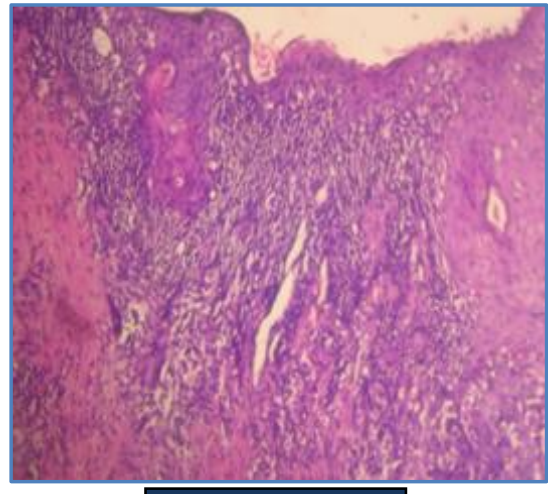

Figure 4 (a)

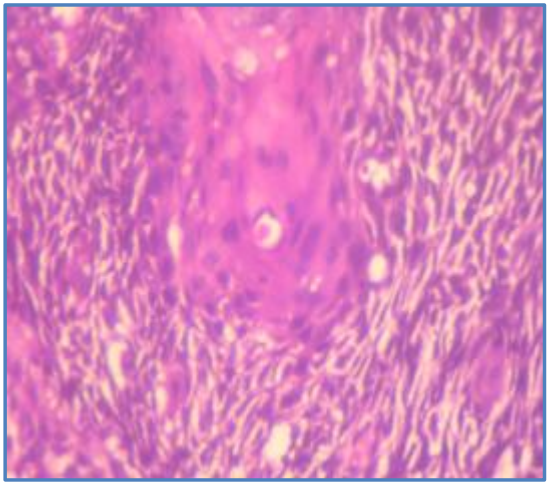

Figure 4 (b)

Fig. 4(a): Lichen planus areas with intraepithelial edema and formation of squamous cell carcinoma (10X).

Fig. 4(b): Shows marked edema in the squamous epithelium with suprabasilar separation. Intraepithelial edema and suprabasal bullae formation is seen as well (20X). 


\section{CASE REPORT}
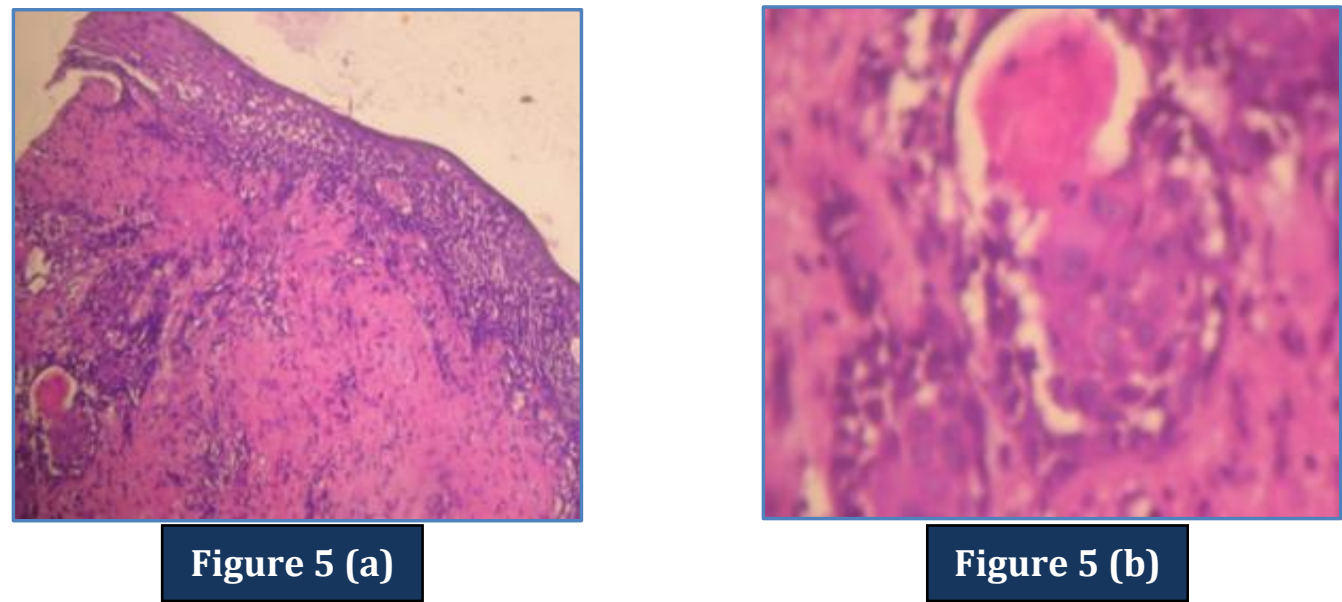

\section{Figure 5 (b)}

Fig. 5(a): Shows formation of pseudo-glandular spaces (10X).

Fig. 5(b): Pseudoglandular spaces are lined by malignant squamous cells in single and multiple layers with keratin material present in the spaces. (40X).

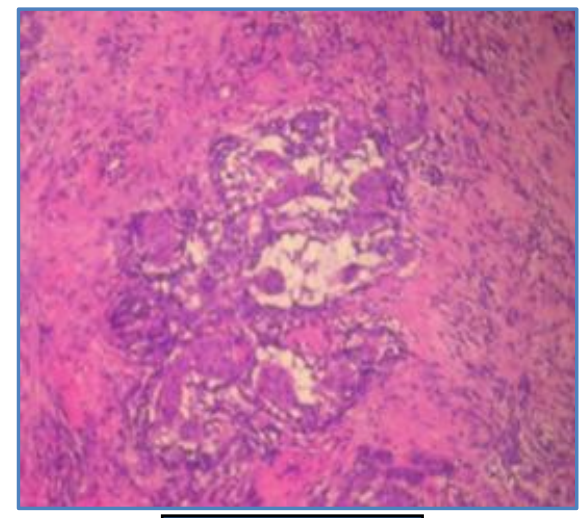

Figure 6 (a)

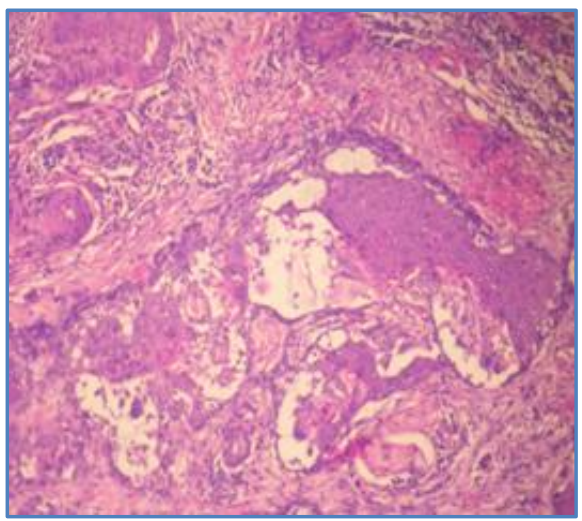

Figure 6 (c)

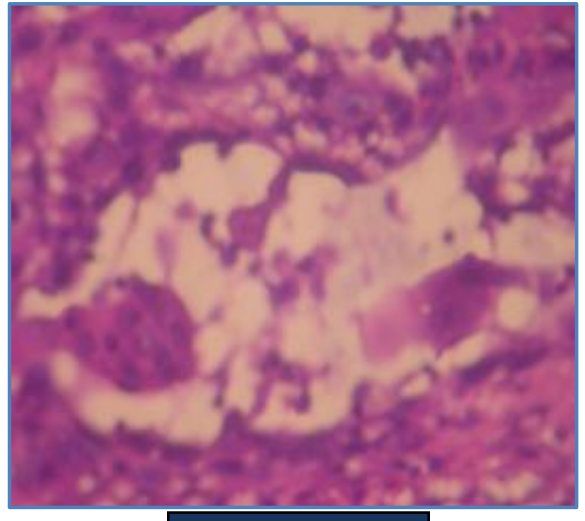

Figure 6 (b)

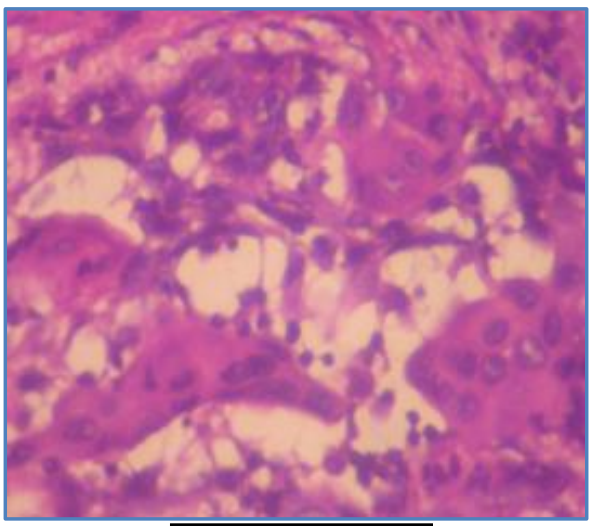

Figure 6 (d)

Fig. 6(a, c): Malignant squamous cells infiltrating the deeper tissue in nests and forming pseudo-glandular spaces (10X).

Fig. 6(b, d): Pseudo-glandular spaces are lined by malignant squamous cells in single or multiple layers and contains acantholytic squamous tumor cells and necrotic debris (40X) 


\section{CASE REPORT}
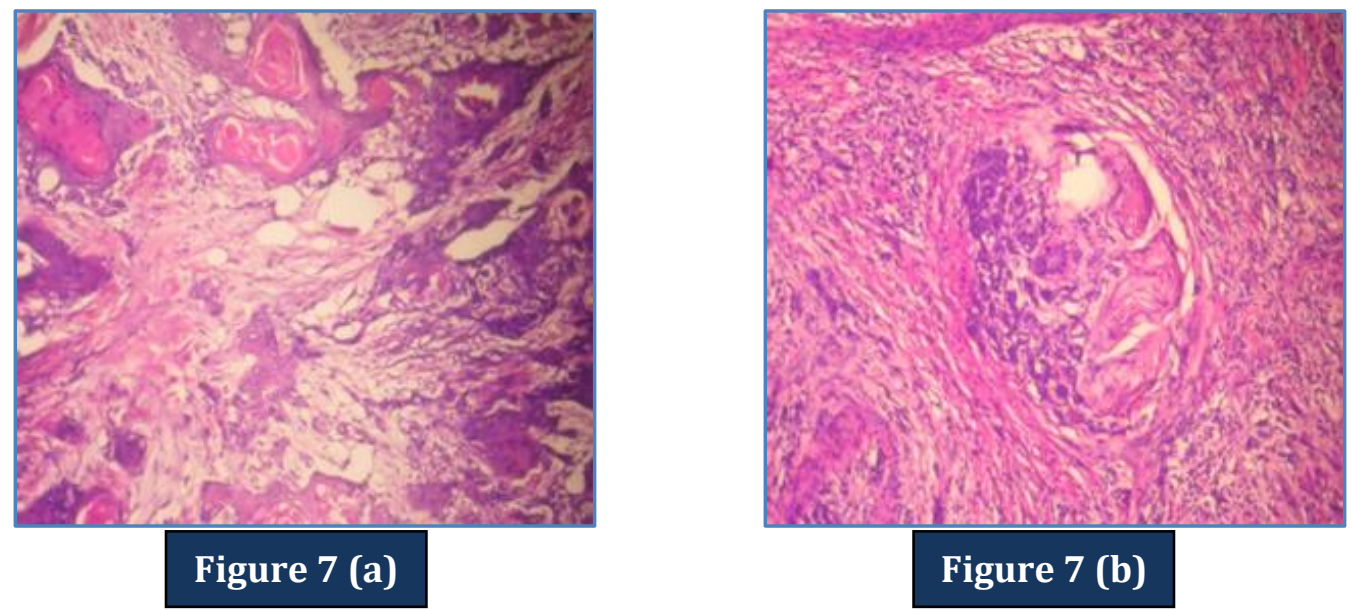

Fig 7(a): Malignant squamous cells in nests and cords, infiltrating the deeper tissue with keratin pearl formation (10X).

Fig. 7(b): Perineurial invasion of the malignant squamous cells (20X)

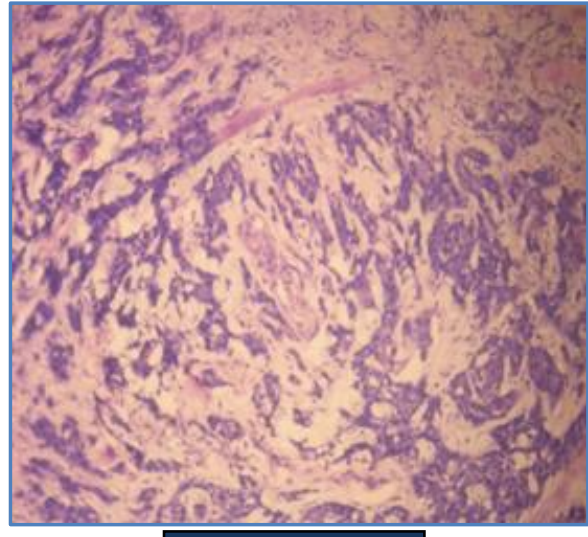

Figure 8 (a)

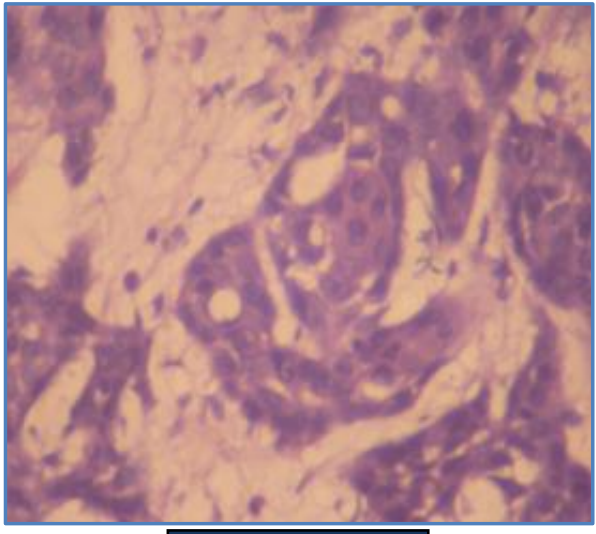

Figure 8 (b)

Fig. 8(a): Squamous cells are arranged in nests and cords with mucoid degeneration of ground substance and pseudo-glandular spaces formation (10X).

Fig. 8(b): Pseudo-glandular spaces where the lumina is lined by single to multiple layers of malignant squamous cells with partial keratinization are also seen in these mucoid areas. (40X). 


\section{CASE REPORT}

\section{AUTHORS:}

1. Mamina Bhoi

2. Sarvesh B. M.

3. P. Viswanathan

4. Rehana Tippoo

\section{PARTICULARS OF CONTRIBUTORS:}

1. $3^{\text {Rd }}$ Year Post Graduate, Department of Pathology, Rajah Muthiah Medical College, Annamalai University.

2. $3^{\text {Rd }}$ Year Post Graduate, Department of Pathology, Rajah Muthiah Medical College, Annamalai University.

3. Professor, Department of Pathology, Rajah Muthiah Medical College, Annamalai University.

4. Professor, Department of Pathology, Rajah Muthiah Medical College, Annamalai University.

\section{NAME ADDRESS EMAIL ID OF THE CORRESPONDING AUTHOR:}

Dr. P. Viswanathan,

Professor, Department of Pathology,

Faculty of Medicine,

Rajah Muthiah Medical College,

Annamalai University,

Chidambaram-608002,

Tamilnadu, India.

E-mail: drpviswanathan1@gmail.com

Date of Submission: 17/02/2014.

Date of Peer Review: 18/02/2014.

Date of Acceptance: 10/03/2014.

Date of Publishing: 27/03/2014. 